Testnevelési Egyetem, Pszichológia és Sportpszichológia Tanszék

\title{
Sportpszichológia a hadseregben - jó gyakorlat a US Army-nál
}

\author{
Dr. Boda-Ujlaky Judit PhD, \\ Dr. habil. Lénárt Ágota PhD
}

Kulcsszavak: sportpszichológiai felkészités, teljesitménypszichológia, US Army, CSF-PREP

A sportpszichológiai módszereket számos teljesítményhelyzetben alkalmazzák, így pl. előadómüvészek és katonai/taktikai egységek munkáját is segítik sportpszichológusok. A katonák számára e teljesítményhelyzetek sokkal súlyosabb következményekkel járnak, mint a sportolók esetében. A sport és a katonaság nagyon sok szempontból hasonlít egymásra: részben az előbbi az utóbbiból származik, másrészt mindkét területen a csapatok is komplex, folyton változó környezetben összehangoltan kell, hogy együttmüködjenek, kognitív és motoros készségeik használatával. Az USA-ban az 1990-es évek eleje óta készítik fel mentális tréning segítségével a katonákat, manapság a Comprehensive Soldier Fitness Performance and Resilience Enhancement Program (CSF-PREP) kezdeményezést alkalmazzák, amely a hadseregben dolgozók és családtagjaik egészségének és teljesítményének javítását célozza, valamint ennek keretében sportpszichológiai módszerek használatát kínálja, továbbá ezek kutatásokkal alátámasztott ellenőrzését végzi.

A magyar tudományos szóhasználatban a sportpszichológia szó a sportteljesítmény (versenyzés) és a testedzés (exercise) pszichológiájának tanulmányozását és in situ alkalmazását is magába foglalja. Az edzés megfelelő elvégzése, a testmozgás során mutatott kitartás, elköteleződés nem csupán a versenyteljesítmény, hanem egészségünk fenntartásának, javításának egyik alapja is és nem utolsósorban a katonák fizikai erőnlétének egyik záloga [1]. Jelen tanulmányban az angolul sport and exercise psychology névvel illetett alkalmazott pszichológiai tudományágat összefoglaló módon, sportpszichológia névvel fogjuk használni. Az utóbbi évtizedek folyamán a sportpszichológia Magyarországon és külföldön egyaránt egyre nagyobb figyelmet kapott minden érintett szereplö oldaláról. Folyamatosan nő azon sporto- 
lók száma, akik a különböző megmérettetésekre sportpszichológussal készülnek. Egyre több edző tartja fontosnak a csúcsteljesítmény előkészítésének és elérésének pszichológiai feltételeivel kapcsolatos ismereteket és a módszerek megfelelő használatát, valamint egyre több szülő szeretné, ha gyermekének több öröme, sikerélménye származna a sportolásból.

A sportpszichológia gyakorlati alkalmazásával kapcsolatos felkésztő munka jellemzőit az American Association for Applied Sport Psychology (AASP) fogalmai és tevékenysége mentén mutatjuk be [2], kiegészítve a magyar gyakorlattal. $\mathrm{Az}$ amerikai példát azért is tartjuk iránymutatónak, hiszen az AASP által elismert, akkreditációval rendelkező sportpszichológusok legnagyobb munkaadója éppen a US Army [3]. Ezután ismertetjük a katonaságnál végzett sportpszichológiai tevékenységgel kapcsolatos amerikai gyakorlat történetét és a napjainkban müködő programot.

\section{A hadsereg és sportpszichológia találkozási pontjai}

A sport és a testedzés területén túl, manapság számos egyéb teljesítményhelyzetben használják a sportpszichológia módszereit, amelyet teljesítménypszichológia néven foglalnak össze. Ily módon segítséget nyújt a különböző előadómüvészetekben (zenészek számára tervezett programok értékelése [4], cirkuszban [5], táncosoknál [6], az előadómüvészetekről összefoglalóan [7]), profi szakács csapatoknál, orvosi teameknél [8], cégvezetőknél és magas kockázatot vállaló munkacsoportoknál [9]. Ez utóbbi kategóriába tartozik a katonákkal, taktikai egységekkel való munka is. A katonai pszichológia ennél tágabb kérdéseket is felölel, így például a kiválasztás, vezetéslélektani kér- dések, pszichoterápiás kezelések, tárgyalások lefolytatása; e helyütt a magas szintü teljesítményre való felkészítés katonai területen való megjelenését vesszük górcső alá. A két terület összevetése abból a szempontból is fontos és tanulságos, mert mindkét esetben a sürgető gyakorlati (alkalmazott) igények és az alapkutatások találkozása meglehetősen nehézkes. Az alapkutatások a szakmai szigorúságot és ellenőrizhetőséget, míg az alkalmazott kutatások az irreleváns feladatok során, mesterséges környezetben mutatott teljesítmény mérését kérik számon a másikon [10, 11], ugyanakkor a gyümölcsöző együttműködés más alkalmazott területek számára is iránymutató lehet. Mindazonáltal jelen tanulmány nem a kutatási kapcsolatokat, hanem a US Army-nál zajló sportpszichológiai tréningprogramokat ismerteti.

Scofield és Kardouni [12] a taktikai sportolók (tactical athlete, a taktikai egységeknél szolgálók megnevezése, akiknek fizikai erőre és kondícióra van szükségük ahhoz, hogy megfelelő színvonalú munkát végezzenek, így pl. a katonák, rendőrök, tüzoltók stb.) és a sportolók összehasonlítása kapcsán kifejtik, hogy a hasonlóságok ellenére a taktikai egységek tagjai nagyobb megterhelésnek vannak kitéve, hiszen a teljesítményromlás és a hibázás következményei sokkal súlyosabbak, mint a sportolók esetében. ${ }^{1}$

1 Jelen cikk szerzői felhívják a figyelmet arra, hogy annak ellenére, hogy a katonák valóban több és folyamatosabb életveszélyes helyzetnek vannak kitéve, valójában több sport is lehet ilyen, a teljesség igénye nélkül pl. ökölvívás, országúti kerékpár, autó- és motorsportok, különböző extrém sportok, vitorlázás, hegymászás. Továbbá a minimális fizikai fittségi tesztek és az egész éves fizikai készenlét is mindennapos részei a sportnak. A fizikai aktivitás és a regenerálódási idő hossza is bejósolhatatlan lehet bizonyos sportokban, ám nem olyan mértékben, mint egy-egy bevetés esetén. 
Egy másik [13] elgondolás szerint mindkét terület azt kívánja meg az egyéntől, hogy (a) komplex és dinamikus környezetben teljesítsen; (b) perceptuális, kognitív és motoros készségeit összehangoltan alkalmazza; (c) taktikai elönyre tegyen szert az ellenfelével szemben; (d) részleges, időben változó információk alapján tevékenykedjen; (e) csapatban és egyénileg is képes legyen hatékonyan dolgozni és (f) stresszteli környezetben. Ez felveti a speciális képzések, föként a kognitív-perceptuális és döntéshozatali tréningek alkalmazásának szükségességét is.

Ami a sportpszichológiai elméletek és gyakorlat alkalmazását illeti, számos kölcsönhatás lehetséges a két terület között. Egyáltalán nem kívánjuk a sportpszichológiai módszerek elsőbbségét hirdetni, mindkét terület kölcsönösen profitál(hat) a másik által alkalmazott módszerek használatából. A sportpszichológia ugyanakkor számos hasonló problémakörben kínál segítséget: ilyen a kiképzés, illetve a bevetés során a fizikai és taktikai felkészítés, a sérülés-rehabilitáció, vagy a hibakezelés. Ilyen módon az USA-ban, ahol mind a sportpszichológiai ellátás fejlett, mind a hadsereg igényei kiemeltek, számos sportpszichológiai program segíti a katonák felkészítését. $\mathrm{Az}$ amerikai hadsereg a világ legnagyobb munkaadója, 3,2 millió munkavállalóval [14]. Az AASP (ld. a bevezetőben) által akkreditált sportpszichológusok legnagyobb „felvásárlója” a hadsereg [15], nem csupán az elöbb említett okokból, hanem azért is, mert a mozgásszegény életmód és az egészségtelen táplálkozás következtében egyre nő az újoncok testtömegindexe és így azok száma is, akik nem képesek teljesíteni a kiképzés végén a fizikai fittségi teszteket (Army Physical Fitness Test, APFT, [16]). A ki- képzés első fázisa katonánként 58 ezer dollárba kerül, a fizikai teszteken elbukók több mint 251 millió dolláros veszteséget termelnek [16], így preferáltak az e költségeket mérséklő támogatási rendszerek. Ilyen kezdeményezés Magyarországon is müködik [17].

\section{Az alkalmazott sportpszichológiai munka jellemzői}

Az alkalmazott sportpszichológia a sportpszichológiának azon ága, amely az utóbbi által kutatott témákat és kialakított elméleteket a gyakorlat számára hasznosítja. Így a sportolók, edzők, szülők, sportoktatók, hobbisportolók számára megvilágítja a teljesítmény-pszichológia aspektusait, ezáltal segít az optimális teljesítmény és élvezet elérésében, az egészség megőrzésének célja mellett. Az alkalmazott sportpszichológiai munka számos módszert, technikát, egyéni- és csoportkonzultációt kombinál a kliens igényeitől függően, általános céljaként mégis az edzéseken, illetve a versenyeken konzisztens teljesítmény eléréséhez szükséges mentális készségek megtanítása fogalmazható meg [18].

A sportpszichológiai munka nagyon sokrétü lehet, ugyanakkor van néhány alapkészség, amelyet minden sportolónak érdemes megtanulnia. Mindegyik érintett kérdés sokkal összetettebb és bonyolultabb, mint amit jelen ismertetö terjedelmileg kezelni képes, így csak említés szintjén foglaljuk össze a legfontosabb tudnivalókat.

Az első fontos készség a szorongás- és energiakezelés a csúcsteljesítmény elérése szempontjából nem hatékony (vagyis túl magas vagy túl alacsony) arousal szint kezelésében nyújt segítséget. Erre szolgálnak többek között a különböző légzéstechnikák, a progresszív relaxáció, az 
autogén tréning, a biofeedback, a meditáció, az imagináció, valamint különböző kognitív technikák, mint pl. a kognitív újrastrukturálás vagy a gondolatstop. Ebbe a témakörbe tartozik továbbá a dühkezelés kérdése is.

A figyelem és koncentráció növelése a környezet vagy a saját test releváns ingereire való fókuszálást jelenti, más, irreleváns ingerek kizárásával. Mivel hol a figyelem kiterjesztése, hol annak beszükítése szükséges, többféle figyelemfejlesztő módszer alkalmazása javasolt.

A különböző célállitási módszereket leggyakrabban a motiváció növelése, a figyelem fókuszálása, illetve a sérülésekből való felépülés elősegítése céljából alkalmazzák. Ebben az esetben is számos technika lehetséges alkalmazásáról beszélhetünk, a készségfejlesztéstől kezdve a célelérés módjának és idejének meghatározásán keresztül a célok elérésének értékeléséig.

Az imagináció az összes érzékleti modalitás együttes jelenlétének elképzelését jelenti annak érdekében, hogy az elmébe tapasztalatokat írjunk, illetve a negatív tapasztalatokat újraírjuk, hiszen az észlelés és a képzelet ugyanazon efferens kópiákat müködteti [19]. Számos területen alkalmazható, így a szorongáskontrollban, a figyelemkontrollban, az önbizalomnövelésben, új készségek tanulásában, sérülésből való felépülés során, végül, de nem utolsósorban mentáltréninghez.

A self talk vagy belső beszéd azt jelenti, hogy miképp szólunk önmagunkhoz, hogyan gondolkodunk önmagunkról. Célja általában egy specifikus viselkedés kialakítása, az önbizalom vagy a figyelmi kontroll növelése, a motiváció vagy az arousal kontrollálása. Általánosságban, a teljesítményt negatív irányban befolyásoló negatív gondolatok azonosítása és felülírása történik.
A csapatépités során segítünk a csapat tagjainak, hogy megfelelően együtt tudjanak dolgozni a kommunikáció javításával, a bizalom, a tisztelet növelésével, illetve a csoport- és egyéni célok, szerepek, feladatok meghatározásával.

A kommunikáció javitása a csapatkohézió növelését, illetve az egyének között zajló interakciók minőségének javítását célozza bármilyen résztvevővel, legyen az szülö vagy a média képviselője. Ide tartozik az aktív figyelem, a hallgatás, az asszertivitás, illetve a nyitott és szabad kommunikációt biztosító környezet kialakításának megtanítása.

$\mathrm{Az}$ időszervezés a rendszeres időbeosztás kialakítását és megtartását célozza, a konfliktusok és a felesleges stressz elkerülése érdekében. Ide tartozik a feladatok jellegének feltérképezése, a feladatokkal kapcsolatos célállítás, a verseny elötti rutin kialakítása, illetve a szerepkonfliktusok kezelése céljából történő önismereti munka.

A sportteljesítmény természetesen több összetevőből áll, minimálisan a fizikai, technikai, taktikai, illetve a pszichológiai felkészültség összjátéka határozza meg. A sportok különböznek a tekintetben, hogy a sportolóknak melyik készségből mennyire van szüksége a csúcsteljesítmény eléréséhez, ugyanakkor kölcsönhatásban is müködnek, vagyis pl. a fizikai felkészületlenség mentális problémákhoz vezet, vagy a technikai problémák mentálisan javíthatók. Azonban a sportpszichológia nem csodaszer, az „egy mondattal helyrerakom" sajnos közkeletü tévedés, és nem is egy szakácskönyv. A teljesítményben megjelenő problémáknak számos különböző oka lehet és fordítva, ugyanazon esemény számos különböző teljesítménybeli problémához vezethet. 


\section{Sportpszichológiai programok a US Army-nál}

Az MST (mental skills training: energiakezelés, célállítás, imagináció, self-talk) jelentőségét már az 1990-es évektől felismerte a hadsereg és kis léptékben tanították is azt a katonáknak [20]. 1993-tól a West Point Akadémián, majd 1999-től mobil egységek közremüködésével segítették a őket. Ez utóbbi gazdasági okokból 2004-ben megszünt. Ugyanebben az évben egy, az egész hadseregre kiterjedő program kidolgozása kezdődött meg, ami 2006-tól Army Center for Enhanced Performance néven müködött a kezdeti kipróbálás és pozitív tapasztalatok után kilenc helyszínen. Fontos megemlíteni, hogy a program nem csupán a sportpszichológiai módszerek alkalmazását tartalmazta, hanem a felsőoktatásban résztvevők tanulási teljesítményének javítását is célozta [10]. A programról részletesen DeWiggins, Hite és Alston (2009, 2010) számolt be [22, 23]. 2010-ben a program a Comprehensive Soldier Fitness része lett és együtt Comprehensive Soldier Fitness Performance and Resilience Enhancement Program (CSF-PREP) néven müködik 12 helyszínen [24]. A program elérhető továbbá a családtagok és a nem harcoló személyzet számára is (Comprehensive Soldier \& Family Fitness Building Resilience Enhancing Performance, CSF2) [25].

A sportpszichológia ebben a tíznapos programban az utolsó napon, egynapos workshopként szerepel. Fő témái:

- a mentális készségek alapjai: a gondolatok, érzelmek, fiziológiai állapotok és a magas teljesítmény jellegzetességeinek, összefüggéseinek tisztázása,

- önbizalom-építés: az önbizalom jellegzetességeinek tisztázása, megfelelő önbizalom felépítése és fenntartása azáltal, hogy az hogyan függ a gondolkodástól és az eseményekre való reakcióktól; a hibák és sikerek hatékony értelmezése, a self-talk technikájának megtanulása,

- célállítás: egy hétlépcsős célállítási folyamat megtanulása, amely az alapvető értékek tisztázásával kezdődik, tulajdonképpen akcióterv készítése, egyéni, illetve egység-célok állítása,

- figyelem-kontroll: a figyelmi fókusz javítása és az újrafókuszálás elősegítésére alkalmas technikák tanulása,

- energiakezelés: oktatás arról, hogy a a stressz hogyan hat a teljesítményre, stresszkezelési, energia-mobilizálási, illetve megfelelő relaxációs és regenerációs technikák tanulása,

- imagináció: a mentáltréning (a fizikai készségek mentális gyakorlása) megismerése, illetve a stresszteli helyzetekre való felkészülés, motiváltság és energiakezelés elsajátítása az imagináció segítségével [26].

$\mathrm{Az}$ átfogó programon kívül több specifikus beavatkozást is végeznek. Ezek mindegyike az idők folyamán változott. Így e helyütt jelenleg is zajló programokat ismertetünk röviden. Ilyen a Sport Psychology for the Soldier Athlete, ami az MST-t tanítja a kiképzés alatt, hat héten keresztül [27] annak érdekében, hogy a kadétok az Army Physical Fitness Tesztet (kétperces felülés, a kétperces fekvőtámasz és a kétmérföldes futás) képesek legyenek végrehajtani. A célállítás a SMART (specifikus, mérhető, elérhető, reális és időhöz köthető célok) módszer elsajátításával történik. Heti elérendő értékeket határoznak meg mindhárom testedzési feladathoz és értékelik azokat. Az imagináció során a tökéletes formát, a maximális erőfeszítést és a sikeres teljesítést vizualizálják. A pozitív self-talk-ot 
motivációs stratégiaként alkalmazzák a figyelem, az önbizalom és a teljesítmény javítása céljából. A résztvevők az imaginációval párosítva célformulát alkotnak pl. „könnyedén és erősen”, miközben a kétmérföldes futást végzik. A szívritmuskontroll az általános egészség és a stresszre adott reakciók szempontjából is fontos. A légzés mélységének és ritmusának változtatása nagy hasznot hoz és önmagában elegendő a szívritmus csökkentésére.

Stresszkezelési program több területen müködik, így a légierőnél [28] és a haditengerészetnél [28, kiképzés során 29], a tartalékosoknál [30], a veteránoknál [31] ám nem mindenki számára érhető el. A program a kognitív viselkedésterápiás háttérrel müködik, amely alapvetően nem sportpszichológiai jellegü.

A perceptuális-kognitív készségek, illetve a döntéshozás javítását célzó programok is sportpszichológusi támogatással működnek [32]. A döntési készségek tréninget Klein [33, 34] 1997-ben dolgozta ki. Feltételezése szerint a pilóták döntései inkább a tapasztalatokon alapulnak, semmint az elöírt eljárások és normatív stratégiák követésén, így a tapasztalatok számát kell gyorsan növelni. Elöször azonosították, mik a feladatuk döntési követelményei, az azokban rejlő nehézségek, a gyakori hibatípusok és azon stratégiák, melyek segíthetnek mindezeken. Aztán mentális szimulációt alkalmaztak, hogy rávilágítsanak a lehetséges hibaforrásokra. Ezután taktikai döntéshozatali játékokat játszottak és megtanulták, hogyan alakítsanak ki saját döntési játékot a további gyakorlás érdekében.

\section{A programok hatása}

A programok hatásosságát a kezdeményezés keretein belül természetesen ellenőrzik. A sportpszichológiai hatásvizs- gálatok (ld. pl. [35, 36, 37]), szignifikáns fejlődésről számolnak be. Azon értékeléseket, amelyek szubjektív beszámolókon, nem pedig objektív teljesítménymérési eredményeken alapulnak, e helyütt nem említjük. Hammermeister, Pickering, McGraw és Ohlson [38] 2010-ben publikált eredményei szerint a katonák pszichológiai profilja összefüggésben van a fizikai fittségi tesztek eredményeivel. Adler, Bliese, Pickering, Hammermeister, Willaims, Harada, Csoka, Holliday és Ohlson [39] újabb vizsgálata kimutatta, hogy egy tízhetes MST (mental skills training) képzésen résztvevo" katonák is, a hadtörténelmet hallgató kontrollcsoporthoz képest, többféle kognitív készséget használtak, nagyobb volt az önbizalmuk a fizikai teszteken, az akadálypályákon jobban teljesítettek függőleges mászáskor, illetve a kezdeti fegyverhasználat során, bár ezeket a hatásokat némileg befolyásolta a nem és a tapasztalat. Ugyanígy, a Sport Psychology for the Soldier Athlete [40] programban résztvevők esetében is szignifikánsan javultak a fizikai fittségi tesztek eredményei és csökkent a bukások aránya.

\section{Összegzés}

A sportpszichológiai módszerek számos módon és probléma esetében használhatók a hadseregben is. Magyar kezdeményezés hiányában az Egyesült Államok többféle programját megvizsgálva ezek hatásosságát feltételezhetjük.

\section{Irodalom}

[1] Eleki Z.: A katonai fittség átfogó értelmezése a Total Force Fitness program alapján. Honvédrovos, 2018, 70(3-4), 14-21.

[2] https://appliedsportpsych.org/about/aboutapplied-sport-and-exercise-psychology/) 
[3] Watson, J., Mugford, A.: AASP Certification: The critical move to an exam-based credential. ISSP 14th World Congress, 10-14 July, 2017, Seville, Spain.

[4] Clark, T., Williamson, A.: Evaluation of a mental skills training program for musicians. Journal of Applied Sport Psychology, 2011, 23(3): 342-359.

[5] Ménard, J. F., Hallé, M.: Circus also needs performance psychology: Facts and realities of consulting at Cirque du Soleil. In Becoming a Sport, Exercise, and Performance Psychology Professional, Psychology Press. 2014, 155-162. pp.

[6] Taylor, J., Estanol, E.: Dance psychology for artistic and performance excellence. Human Kinetics, 2015

[7] Nordin-Bates, S. M.: Performance psychology in the performing arts. The Oxford handbook of sport and performance psychology, 2012, 81-114.

[8] Cooke, N. J.: Interactive team cognition: Focusing on team dynamics. 14th Congress of Sport Psychology, July, 2015, Bern, Switzerland

[9] Hays, K. F.: Performance psychology in action: A casebook for working with athletes, performing artists, business leaders, and professionals in high-risk occupations. American Psychological Association, 2009.

[10] Goodwin, G. F.: Psychology in sports and the military: Building understanding and collaboration across disciplines. Military Psychology, 2008, 20(sup1), S147-S153.

[11] Fiore, S. M., Salas, E.: Cognition, competition, and coordination: The "why" and the "how" of the relevance of the sports sciences to learning and performance in the military. Military Psychology, 2008, 20(sup1), S1-S9.

[12] Scofield, D. E., Kardouni, J. R.: The tactical athlete: a product of 21 st century strength and conditioning. Strength \& Conditioning Journal, 2015, 37(4): 2-7.

[13] Ward, P., Farrow, D., Harris, K. R., et al.: Training perceptual-cognitive skills: Can sport psychology research inform military decision training?. Military Psychology, 2008, 20(sup1.), S71-S102., p. S86.

[14] Chang, S.: US Military is the largest employer in the world. Marketwatch, 2015. https://www.marketwatch.com/story/usmilitary-is-the-largest-employer-in-theworld-2015-06-17.
[15] Watson, J., Mugford, A.: AASP Certification: The critical move to an exam-based credential. ISSP 14th World Congress, 10-14 July, 2017, Seville, Spain.

[16] Meyer, V. M.: Sport Psychology for the Soldier Athlete: A Paradigm Shift. Military medicine, 2018, 183(7-8): 270-277.

[17] Eleki Z.: A katonai fittség átfogó értelmezése a Total Force Fitness program alapján. Honvédrovos, 2018, 70(3-4): 14-21.

[18] https://appliedsportpsych.org/about/aboutapplied-sport-and-exercise-psychology/)

[19] Grush, R.: The emulation theory of representation: Motor control, imagery, and perception. Behavioral and Brain Sciences, 2004, 27(3): 377-396.

DOI:10.1017/S0140525X04000093

[20] Hammermeister, J., Pickering, M. A., McGraw, L., \& Ohlson, C.: Relationship between psychological skill profiles and soldier physical fitness performance. Military Psychology, 2010, 22(4): 399-411.

[21] Hammermeister, J., Pickering, M. A., McGraw, L., Ohlson, C.: Relationship between psychological skill profiles and soldier physical fitness performance. Military Psychology, 2010, 22(4): 399-411.

[22] DeWiggins, S., Hite, B., Alston, V.: A fourphase approach to mental skills training: From skill acquisition to application. Poster session presented at the Association for Applied Sport Psychology annual conference, 2009, Sept., Salt Lake City, UT.

[23] DeWiggins, S., Hite, B., Alston, V.: Personal performance plan: Application of mental skills training to real-world military tasks. Journal of Applied Sport Psychology, 2010, 22(4), 458-473.

[24] Hammermeister, J., Pickering, M., Lennox, A.: Military applications of performance psychology methods and techniques: An overview of practice and research. The Journal of Performance Psychology, 2011, 3: $1-14$.

[25] https://www.ausa.org/publications/comprehensive-soldier-and-family-fitness-buildingresilience-enhancing-performance

[26] Reivich, K. J., Seligman, M. E., McBride, S.: Master resilience training in the US Army. American Psychologist, 2011, 66(1): 25-34.

[27] DeWiggins, S., Hite, B., Alston, V.: Personal performance plan: Application of mental skills training to real-world military tasks. 
Journal of Applied Sport Psychology, 2010, 22(4): 458-473.

[28] Robson, S., Manacapilli, T.: Enhancing performance under stress: Stress inoculation training for battlefield airmen. 2014, Rand Project Air Force Santa Monica, CA.

[29] Clifton, H. L., Matsangas, P., Shattuck, N. L.: Assessment of Stress Inoculation Training at the US Navy Surface Warfare Officer School. Monterey, California. Naval Postgraduate School, 2020.

[30] Doss, A. N.: Stress Inoculation Training in ROTC Cadets. 2019. https://scholarworks. sfasu.edu/etds/325/

[31] Jackson, S., Baity, M. R., Bobb, K., et al.: Stress inoculation training outcomes among veterans with PTSD and TBI. Psychological Trauma: Theory, Research, Practice, and Policy, 2019, 11(8), 842-850. https://doi.org/ $10.1037 / \operatorname{tra} 0000432$

[32] Ward, P., Farrow, D., Harris, K. R., et al.: Training perceptual-cognitive skills: Can sport psychology research inform military decision training?. Military Psychology, 2008, 20(sup1.): S71-S102.

[33] Klein, G. A.: Developing expertise and decision making. Thinking and Reasoning,1997, 3: $337-352$.

[34] Klein, G. A.: How can we train pilots to make better decisions? In H. F. O'Neil \& D. H. Andrews (Eds.), Aircrew training and assessment, 2000, 165-195 pp., Mahwah, NJ: LEA.

[35] Hall, C. R., Rodgers, W. M.: Enhancing coaching effectiveness in figure skating through a mental skills training program. The Sport Psychologist, 1989, 3(2): 142-154.

[36] Thelwell, R. C., Greenlees, I. A.:The effects of a mental skills training package on gymnasium triathlon performance. The Sport Psychologist, 2001, 15(2): 127-141.

[37] Blakeslee, M. L., Goff, D. M.: The effects of a mental skills training package on equestrians. The Sport Psychologist, 2007, 21(3): 288-301.

[38] Hammermeister, J., Pickering, M. A., McGraw, L., Ohlson, C.: Relationship between psychological skill profiles and soldier physical fitness performance. Military Psychology, 2010, 22(4): 399-411.

[39] Adler, A. B., Bliese, P. D., Pickering, M. A., et al.: Mental skills training with basic combat training soldiers: A group-randomized trial. Journal of Applied Psychology, 2015, 100(6): 1752-1764.
[40] Meyer, V. M.: Sport Psychology for the Soldier Athlete: A Paradigm Shift. Military medicine, 2018, 183(7-8): 270-277.

\section{J. Boda-Ujlaky PhD, \\ Á. Lénárt PhD}

\section{Sport psychology in military settings - good practices at the US Army}

Lately, sport psychological methods are used in many performance-related fields, like performing arts and military/tactical settings. For soldiers these situations lead to more serious consequences than for athletes. Sports and military have many things in common: partly many sports come from combat settings, on the other hand, military/ tactical teams need to collaborate in a complex, continually changing environment, using their cognitive and motor skills, just like sport teams. In the US there are mental skills trainings for the soldiers form the '90s. Nowadays the Comprehensive Soldier Fitness Performance and Resilience Enhancement Program (CSF-PREP) initiative is appied, that aims the enhancement of the performance and mental health of the military employees and their family members, and within this framework offers sport psychological methods, moreover, evaluates the effectiveness of the program through scientific investigation.

Key-words: Sport psychogical preparation, performance psychology, US Army, CSF-PREP

Dr. Boda-Ujlaky Judit, PhD 1122 Budapest, Alkotás u. 44. 